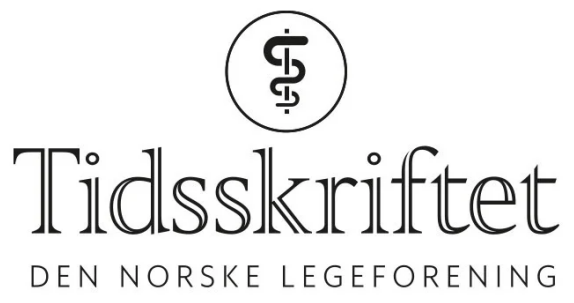

\title{
Mening i livet er knyttet til sosialt fellesskap
}

FRA ANDRE TIDSSKRIFTER

KETIL SLAGSTAD

Tidsskriftet

For japanske studenter var mening i livet knyttet til opplevelsen av at andre hadde behov for en, ifølge en ny kvalitativ studie. 


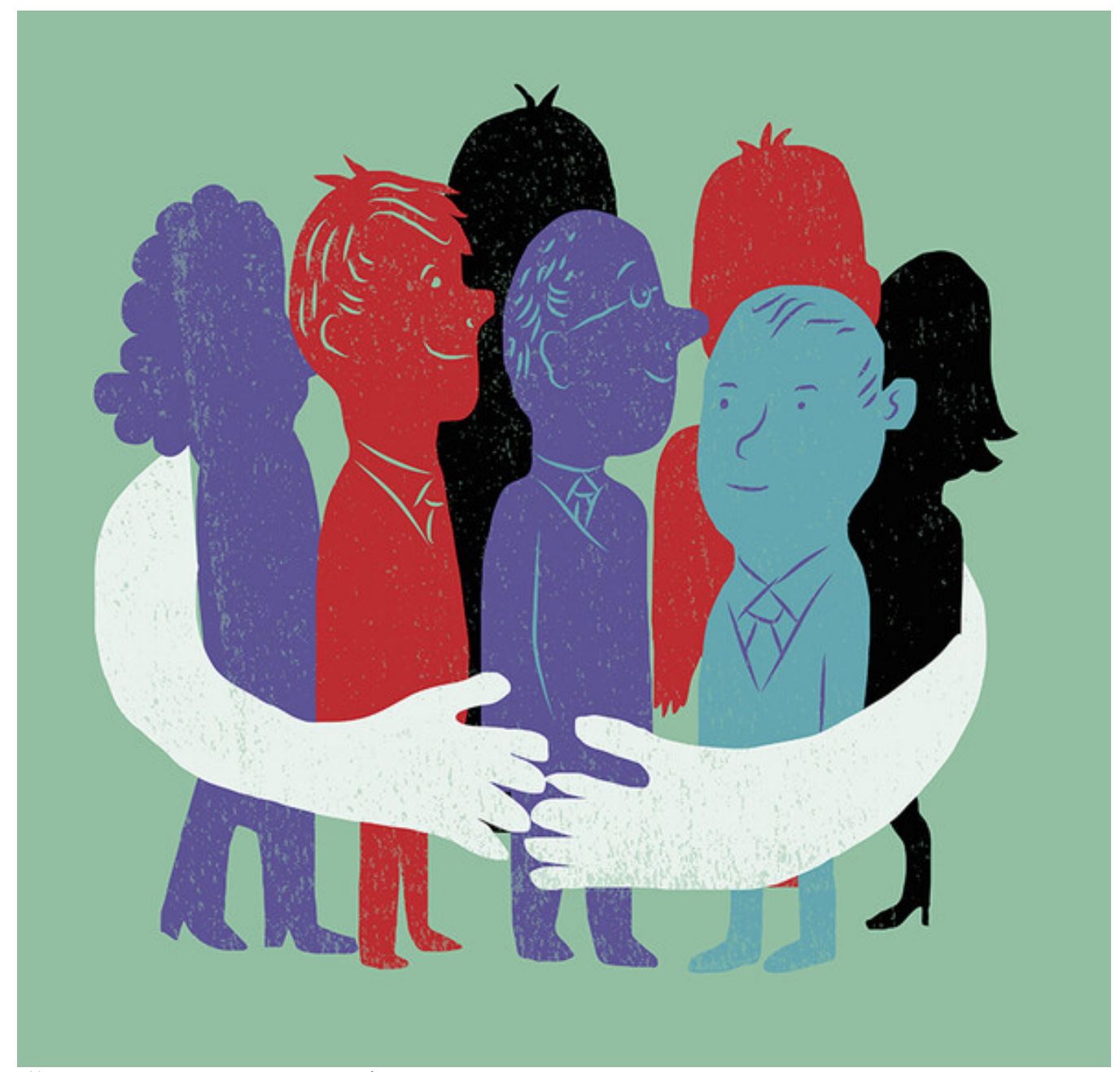

Illustrasjon: Jens Magnusson / NTB

Selvmord er den viktigste årsaken til død blant unge i Japan, og ensomhet er en viktig risikofaktor. I en studie som nylig er publisert i tidsskriftet Transcultural Psychiatry, ble kvalitative intervjuer med 24 japanske studenter i 20-årene analysert (1). Flertallet av studentene var kvinner, og de semistrukturerte intervjuene dreide seg om to hovedtemaer: opplevelsen av å være viktig for andre, opplevelsen av mening i livet og hva som gjør livet verdt å leve (på japansk hhv. ikiru imi og ikigai).

Studentene beskrev at opplevelsen av å være viktig for andre var nært knyttet til hva som gjør livet verdt å leve. Mening i livet var med andre ord knyttet til å det å ha relasjoner til andre. Funnene ble deretter sammenliknet med kvalitative undersøkelser blant unge personer med selvmordstanker som delte opplevelser og erfaringer på internett. Personene ga uttrykk for ekstrem ensomhet, eksistensiell smerte og ønske om at noen hadde behov for en, men det ble ikke funnet en tilsvarende sammenheng som hos studentene mellom følelsen av å være viktig for andre og følelsen av å ha mening i livet. Hos studentene var mening i livet uløselig knyttet til sosialt fellesskap, mens for dem som deltok i diskusjoner på internett, var spørsmålet om mening i livet abstrakt og vanskelig å besvare.

- Funnene i denne studien samsvarer med klinisk erfaring med personer som står i fare for å begå selvmord, der det gjelder å mobilisere sosiale nettverk for å dempe ensomhet og ivareta vedkommende, sier Suraj Thapa, som er førsteamanuensis ved Klinikk for psykisk helse og avhengighet ved Universitetet i Oslo. Han mener at en kvantitativ studie vil kunne gi mer generaliserende kunnskap på tvers av populasjoner i ulike land.

- Studien er særlig aktuell i dagens situasjon med koronapandemien, der vi vet at mange blir sittende isolert og ensomme hjemme. De sosiale restriksjonene gjør livet enda vanskeligere for personer som allerede hadde psykiske vansker, sier han. Også i Norge vet vi 
at en opplevelse av mening i livet ofte er knyttet til det å være del av et sosialt nettverk, noe som igjen kan forebygge psykiske vansker.

- Som psykiatere minner dette oss om at vi bør jobbe mer med å styrke enkeltpasienters sosiale nettverk, sier Thapa, som mener at vi også må være flinkere til å involvere oss politisk for å sikre at denne kunnskapen blir integrert i undervisning og arbeidsliv.

\section{LITTERATUR}

1. Ozawa-de Silva C. In the eyes of others: Loneliness and relational meaning in life among Japanese college students. Transcult Psychiatry 2020; 57: 623-34. [PubMed][CrossRef]

Publisert: 8. februar 2021. Tidsskr Nor Legeforen. DOI: 10.4045/tidsskr.20.0941

(C) Tidsskrift for Den norske legeforening 2023. Lastet ned fra tidsskriftet.no 26. april 2023. 